Entry

\title{
The New Sociology of Religion
}

\author{
Roberto Cipriani (1)
}

check for

updates

Citation: Cipriani, R. The New Sociology of Religion. Encyclopedia 2021, 1, 822-830. https://doi.org/ 10.3390/encyclopedia1030063

Academic Editors: Chia-Lin Chang, Michael McAleer and Philip Hans Franses

Received: 12 July 2021

Accepted: 12 August 2021

Published: 18 August 2021

Publisher's Note: MDPI stays neutral with regard to jurisdictional claims in published maps and institutional affiliations.

Copyright: (c) 2021 by the author. Licensee MDPI, Basel, Switzerland. This article is an open access article distributed under the terms and conditions of the Creative Commons Attribution (CC BY) license (https:// creativecommons.org/licenses/by/ $4.0 /)$.
Department of Education Sciences, Roma Tre University, via del Castro Pretorio 20, 00185 Rome, Italy; roberto.cipriani@tlc.uniroma3.it

Definition: The new sociology of religion differs from the classical and mainstream sociology, which was in force until the end of the last century, in that it no longer considers religion only as an independent variable, but places it together with other dependent variables, so that it becomes possible to investigate new themes, especially those that do not consider religious involvementfrom atheism to the phenomenon of 'nones' (non-believers and non-practicing), from spirituality to forms of para-religions and quasi-religions and the varied set of multiple religions.

Keywords: sociology; religion; secularization

\section{Introduction: From Secularisation to Nones}

After the start given by the classical authors (in particular Durkheim and Weber, but also Simmel and W. James) to the scientific approach aimed at the knowledge of the religious fact, subsequent scholars have ventured, firstly, into the examination of religious practice (in the 1950s and 1960s) and then into the vexata quaestio of secularisation [1,2], a topic that has held sway for several decades, until the end of the last century and the beginning of the new millennium (the peak of interest was recorded between the second part of the sixties and the first part of the seventies). Subsequently, but particularly since the 1980s, the discourse on the post-secular or post-secularisation has developed [3-5]. Thus, albeit by way of contrast, the topic of secularisation has remained central even in the new millennium [6]. In the meantime, however, other research has been conducted on entirely new (or almost new) topics: prayer [7], spirituality [8,9], Eastern religions [10] and Chinese religions in particular [11-14], everyday [15] and/or lived religion [16], digital religion [17-19], gender [20], visual analysis [21,22], the phenomenon of megachurches [23-26], televangelism [27], Protestantism [28], atheism [29-31] and so-called nones [32,33]. Finally, in some cases, there has been a slide (understood as a fact and certainly not as an evaluation) towards para-religious or quasi-religious aspects, like in studies on Scientology [34,35], UFOs [36] or Pastafarians [37] (pp. 132-140) [38]. These contents were previously absent or poorly considered and are now visibly emerging, occupying the spaces of the most important journals, dedicated encyclopaedias and series. If the beginnings were characterised by a rather confessional propensity (for example, what is now the journal Sociology of Religion was called American Catholic Sociological Review from 1940 to 1963 and Sociological Analysis from 1964 to 1992), then gradually religious sociology became sociology of religion and ultimately of religions. In this regard, the diachronic dynamics of the original Conférence Internationale de Sociologie Religieuse (1948), which then became the Conférence Internationale de Sociologie des Religions (1981), and finally the Société Internationale de Sociologie des Religions (1989), is exemplary.

\section{Current Status: New Developments}

Sociologies from countries that have not been present in the past are beginning to appear on the international scene just now, either because of language barriers or because of difficulties in entering international publishing, especially in English. There are three main reasons for the new opportunities offered to the emerging sociologies: 
firstly, the compilation of encyclopaedias of a universal character which also contemplate, as far as possible, contributions relating to themes and authors that do not recur in the better-known literature; secondly, the addition of manuals and companions on a broad international scale dedicated to the sociology of religion; and, finally, the availability of online journals with open access - this novelty makes accessible unusual data and analyses coming from territorial contexts that are usually not taken into consideration, also due to the lack of adequate information and linguistic tools that are at least sufficient for a broad understanding.

As far as the encyclopaedias are concerned, it is worth mentioning, first of all, the valuable work carried out by Adam Possamai and Anthony J. Blasi, editors of The SAGE Encyclopedia of the Sociology of Religion [39], who have broadened the perspective provided by other similar works [40,41], signalling the existence of further tracks for the discipline, including religious radicalisation [42], anti-Semitism [43] and Islamophobia [44]. For the numerous handbooks (and related volumes) published since 2000, reference can be made to those by Malcolm Hamilton [45]; Steven Sharot [46]; Michele Dillon [47]; Phil Zuckerman [48]; Keith A. Roberts [49]; Helen Rose Ebaugh [50]; Ronald Johnstone [51]; James A. Beckford and N. J. Demerath III [52]; Kevin J. Christiano, William H. Swatos and Peter Kivisto [53]; James R. Lewis [54]; George N. Lundskow [55]; Meredith McGuire [56]; Peter B. Clarke [57]; Grace Davie [58]; Roberto Cipriani [59]; Elisabeth Arweck and Mathew Guest [60]; Michael O. Emerson, William A. Mirola and Susanne C. Monahan [61]; Inger Furseth and Pål Repstad [62]; David Yamane [63]; Detlef Pollack, Volkhard Krech, Olaf Müller and Markus Hero [64]; Jayeel Cornelio, François Gauthier, Tuomas Martikainen and Linda Woodhead [65]. Some of these texts have had multiple editions, thus showing a growing interest in the discipline, including the work of Christiano, Swatos and Kivisto; Cipriani; Davie; Johnstone; McGuire; and Roberts.

At the level of journals, two important events took place in the same year: the birth of a widely distributed publication such as Religions, which, since 2010, has selected and published articles of various cultural and scientific disciplinary backgrounds and is freely accessible online. Scrolling through the list of monographic topics covered, one can follow step by step the dynamics of religious phenomenology in various parts of the world. Up to 2015 , four issues per year were published, later twelve, a sign of considerable success, given the high number of readers for each article (from a few hundred at least to several thousand in the most interesting cases). The review of Religions includes research articles, reviews, communications and reports on research projects, also with a multidisciplinary slant.

The other initiative also launched in 2010 was the Annual Review of the Sociology of Religion, under the direction of Enzo Pace, Luigi Berzano and Giuseppe Giordan, as if to resume the interrupted series of Internationales Jahrbuch für Religionssoziologie (International Yearbook for the Sociology of Religion), which began in 1965 and ended in 1973. The topics covered by the Annual Review of the Sociology of Religion are, year by year, in order: youth, politics, methods, prayer and spirituality, monasticism, the Internet, atheism, Pentecostals and the body, Catholicism, interreligious dialogue, Chinese religions, religious freedom.

Another remarkable step has been taken by Fenggang Yang of Purdue University, who founded and has been directing, since 2014, the new Review of Religion and Chinese Society, which thus fills a long-standing gap regarding the presence of the sociology of religion in the Asian area.

\section{Diversity: Paradigm Changes}

In the past, the paradigm that religion was dependent on other sociological variables was in force, then the idea that it had its autonomy [66] took over, which in fact can be seen through the theory of rational choice [67] to be made among the different possibilities offered by the persistent socio-religious pluralism [68]. Having also overcome the hypothesis of a so-called strong programme (religion as an independent variable) in the field of sociology of religion $[69,70]$, we have observed a tendency to go beyond the old paradigms, which have proved incapable of explaining and interpreting the complexity and differen- 
tiation of religions. David Yamane [63] (pp. 5-6), in particular, has pointed out that the sociology of religion is moving to overcome traditional classical frameworks, addressing itself well beyond Christianity, congregations, beliefs, boundaries, modernity and religion too. This perspective suffers greatly from the peculiarly American contextualisation of the approach, but to some extent, it hits the mark, especially as regards the observation of an unusual enlargement of the discipline, which has gone beyond its specific object. However, Yamane's observations have a good deal of reliability, if one considers that the sociology of religion is actually frequently limited to the examination of the Christian world, neglects what happens outside the sacred congregational enclosures (temples, churches, mosques, synagogues and so on), overestimates the weight of religious practice, prefers to investigate the local situation without questioning what is happening in the surrounding world, thus denoting a certain provincialism (parochialism). It keeps in mind only one specific form of modernity, whereas in the sociological field, the so-called multiple modernities have long been established [71]. Finally, probably the most significant development concerns religion itself, since there is an increasing tendency to analyse non-religion, i.e., atheism, the so-called nones (non-believers, indifferent, agnostics, non-members, atheists, neutrals) and also here it is another neologism, the so-called dones, i.e., those who have left religion. The increase in nones and dones casts doubt on the very future of religion [72]. Yamane, therefore, proposes to include the subject of both of these last two categories within the general framework of any empirical research, assuming that the aforementioned ways of addressing the religious question are entitled to full citizenship, so to speak, within the sphere of scientific knowledge applied to the religious fact. Ultimately, "whether in the long run the sociology of religion will consolidate around one or a few paradigmatic approaches is uncertain. In the near term, it seems likely to continue to build on past insights while pushing beyond their particular blindnesses" [63] (p. 6). Sexuality and transnationalism too could be mentioned as topics of interest to the discipline. But the developing areas are also others [73,74].

\section{New Progress: Multiple Religiosities}

Certainly, there has been a significant increase in scholars and sociological studies on religion in recent decades. The perspectives of analysis have widened-researchers no longer always and only move within their own confessional cultures of reference, but rather push themselves to explore other terrains, other religious forms, unusual ways of attitudes and behaviours of a spiritual nature or similar to it. In other words, the horizons have expanded considerably, making it possible to carry out a comparative analysis that in the past did not have many significant examples of investigation. In other words, the universality of the religious phenomenon has been widely confirmed and has favoured multiple cognitive paths, so much to legitimise the use of a concept that, in the wake of Eisanstadt's [71] multiple modernities, corresponds to the idea of multiple religiosities; that is, of stratified and articulated religious presences that follow different paths in their phenomenology. This happens in a highly globalised and differentiated context, which shows several typologies, due to the continuous transformations taking place in local societies, which are affected by the impact of transversal trends, able to reach almost every corner of the planet, providing reasons and convictions for the achievement of peculiar identities at an economic and political, cultural and religious level-in Russia as in the United States, in India as in Nigeria, in China as in Brazil and so on. We can, therefore, speak of multiple Islamic modernities [75,76], but also of a multiple Confucianism, typical of East Asia [77].

It is no coincidence that Adam Possamai and Anthony J. Blasi [39] (p. XXVI) cited Eisenstadt and his multiple modernities in the introduction to their The SAGE Encyclopedia of the Sociology of Religion: "today, in globalisation in which religion is less influenced by nations, theories have to adapt themselves to transnational movements and need to reconsider understandings about religion that can no longer be homogeneous. It is indeed more and more difficult today to speak about religion as a universal category. Religion is 
adaptable and is understood differently within different contexts. Shmuel Eisenstadt's work on multiple modernities has certainly been key to sociologists of religion to understand that religion can be practiced and understood differently and that the secular sphere that dominates religion can be a restricted or a very fluid one, depending again on the context. We refer to our contemporary period as one of post-secularism, as if religions can now be expressed freely in the public sphere. However, in this context, the prefix 'post' is a misnomer. We are still in a secular period even if it is more open to religious beliefs and practices than was the immediate post-1960s period".

Starting from these considerations on the continuum of secularisation, the editors of the Encyclopaedia immediately opened the discussion on the novelties of the sociology of religion, stressing that "religion has moved to the digital world as well, and as with other types of social research, sociologists of religion are coming to grips with what questions to ask and how to find answers. New approaches, such as big data analysis and online ethnography, are developing in this field of research. This, again, reflects the fact that religion can adapt itself to any new environment and is a persistent phenomenon" [39] (p. XXVI).

\section{Beyond Secularisation: Diffused Religion; Beck's Proposal}

A significant development of the theses on secularisation is due to Ulrich Beck, who advanced a new interpretative proposal of the diffusion of religion in the form of the experience of a personal God. Whoever wants to escape hierarchies, dogmas, practices, official beliefs, ideological evaluations and the authoritarianism of structures stabilized over time, builds his own way of being religious (or not religious) — which nevertheless relates to the religiosity proposed by churches and by movements and groups, communities and organizations-and comes to terms with the truths claimed and propagated by the various religious denominations. The option that derives from this, that of a personal God, seems very functional to the individual needs of social actors grappling with multiple and complex, risky and unpredictable problems, which do not always find adequate answers in the recipes proposed by historical, traditional, consolidated religions.

This opens up a scenario that allows people to glimpse a kaleidoscope of variations on the religious theme, not necessarily in conflict with each other or even with the classical models, which nevertheless remain in the background, representing a wide-ranging horizon, where systems of socialization continue to operate with more or less effective results. Even though the latter seem to be diminishing in their scope, they remain influential, even after many years and in key existential circumstances.

The historical precipitating factor in all of this is the return to a sort of polytheism according to the interpretative key of a religious individualism that results in a dual orientation, favouring both the religious solution and its negation, without renouncing the search for transcendence. Death, on the other hand, escapes this kind of consideration and is not included in the list of what is qualified as an "ultimate meaning", attributed rather to the private, individual world. For Beck, moreover, religious individualization presents itself as a paradox, since religion promotes memory, strengthens ties, fosters collective identities and spreads strong socializing rituals. However, it is from religion itself that individualization takes its cue, insofar as it is founded on the faith of the individual subject and on his or her freedom of choice.

The very promise of eternal life as a form of defeat for physical death is defined by Beck as a disturbing and isolating invention at the same time, a sort of test that leads to eternal life or not, according to the type of life lived. It should be emphasized, however, that the individualization of religion, when and if it leads to the religiosity of the personal God, is not only very different from the individualization in religion, which could also create problems for institutionalized religious forms, unless the latter seek solutions of compromise, adaptation and conciliation.

To make his reading of religious reality even more explicit, Beck proposed ten fundamental theses that are well suited to the theme of diffused religion: first, the diffusion 
of religious faith is directly proportional to the presence of reasons for uncertainty in existential paths; without going towards the disappearance of religion, a new anarchic mode of religion appears on the horizon, disrespectful of the existing and its usual norms; the individualization of religion is connected to that of society as a whole-families, classes and social groups; institutional images lose relevance, giving way to new words and new symbols; religious practice declines, new forms are amplified that are more fluid and liquid-elusive, as Bauman would say; there is a privatization of religion, but at the same time, it recovers ground in public space (Casanova); the so-called religious truth is transformed both at the institutional and individual level; individualized religion retraces the same symbolic paths of the institutional religious sphere in an evident substantial continuum; the personal God comes at the end of an itinerary that has been institutional, traditional, almost without interruption with the past; the future presents various scenarios, including the aversion to individualized religion, the affirmation of religion in the public sphere (Habermas) and an inclusive perspective of each religion, which relates to other religions, recognizes their contribution and accepts a continuous and open comparison. In this way, religions acquire a universal citizenship that has never been experienced before. The greater diffusion of religions then legitimizes the very expression of "religious universalism" and confirms the tendency towards cosmopolitanism.

\section{Conclusions and Prospects}

Nowadays, the sociology of religion is in very good standing. Think of the work by Charles Taylor [78], A Secular Age, a seminal contribution to the theoretical approach, in terms of an immanent frame (a new concept in the field) through which to express the conditions of belief-that our society is governed by reason. Taylor described how we put ourselves in the world and the idea that we have of it; this is the immanent frame, used to capture and understand the space in which we live. We are in a world where gods and final causes can be eliminated. Within this immanent frame, the relevant thing is this-worldly and self-referential, because the individual is the measure of the good. We are at the beginning of a new age of religious searching. The immanent frame allows for something beyond, but, at the same time, we are oriented towards the closure and the transcendence too. It is no coincidence that the Social Science Research Institute has supported a blog called The Immanent Frame, on secularism, religion and the public sphere.

Another relevant suggestion came from Robert Bellah [79], in the book Religion in Human Evolution: From the Paleolithic to the Axial Age, which took up and broadened his previous analytical perspective [80], considered a cornerstone of the sociology of religion, especially in terms of socio-cultural interpretation of the religious phenomenon. Bellah [81] placed himself at the centre of the debate on the axial age of Jasperian derivation and dialectically rejoined the aforementioned work of Taylor.

Meanwhile, other original topics, to which little attention had been paid in the past, are now being proposed in the scholarly arena, such as the issue of abandonment of one's religion [82] and the opposite phenomenon of conversions [83], gender diversity [84,85], migration [86], mass media [87,88], developments in new Asian religious movements [89] and the contrast between the secular and religious in urban structures in Asia [90], the problems of violence [91] and the relationship between conspiracy theories and religion [92], connections between ecology and religions [93], those concerning peace and conflict [94], the connections between cities and religion [95,96] and sport and religion [97], monasticism [98], religious diversity [99], chaplaincy and religious diversity in prisons [100-102], language [103], the economic aspects of religions [104], legislative issues (especially concerning freedom of religion and human rights) [105-110], political issues [111-113] and globalisation [114]. The methodology only remains somewhat overshadowed, but there is no shortage of relevant contributions [115].

Amidst the 'religious turn' within European philosophy at present, the growth of the study of the phenomenology of religion represents another novelty. 
Some atlases on the spread of religions are valuable [116,117]. The same applies to databases [118]. The specific sociologies of religion with a national character have also developed to such an extent that they now deserve special treatment [119]. The attempt of Spickard [120] to offer a different, non-Western view of the sociology of religion should also be mentioned, together with contributions that relate to the Eastern Orthodox Christianity [121,122].

Ultimately, the basic scenario seems to be that of a widespread but uncertain religion [123,124], a perspective already intercepted by Robert Towler in 1984 and, not surprisingly, proposed once again [125]. We are, therefore, dealing with a kaleidoscope of approaches (pp. 1-20 in [74]) that testify to vitality and liveliness that are more pronounced than ever, and which presage further progress in scientific knowledge applied to religions.

Funding: This research received no external funding.

Data Availability Statement: No data available.

Conflicts of Interest: The author declares no conflict of interest.

Entry Link on the Encyclopedia Platform: https:/ / encyclopedia.pub/14267.

\section{References}

1. Martin, D. The Religious and the Secular. Studies in Secularization; Routledge \& Kegan Paul: London, UK, 1969.

2. Martin, D. On Secularization. Towards a Revised General Theory; Ashgate: Burlington, VT, USA, 2005.

3. Habermas, J. Secularism's crisis of faith: Notes on post-secular society. N. Perspect. Q. 2008, 25, 17-29. [CrossRef]

4. Dillon, M. Postsecular Catholicism. Relevance and Renewal; Oxford University Press: New York, NY, USA, 2018.

5. Beaumont, J. (Ed.) The Routledge Handbook of Postsecularity; Routledge: Abingdon, UK, 2020.

6. Bruce, S. Secularization; Oxford University Press: New York, NY, USA, 2011.

7. Giordan, G.; Woodhead, L. (Eds.) A Sociology of Prayer; Ashgate: Burlington, VT, USA, 2015.

8. Jupp, P.C.; Flanagan, K. A Sociology of Spirituality; Routledge: London, UK, 2007.

9. Ammerman, N.T. Sacred Stories, Spiritual Tribes. Finding Religion in Everyday Life; Oxford University Press: Oxford, UK, 2013.

10. Pouillon, F.; Vatin, J.C. (Eds.) After Orientalism: Critical Perspectives on Western Agency and Eastern Re-appropriation; Brill: Leiden, The Netherlands, 2015.

11. Yuet, C.A. (Ed.) Religion in Contemporary China. Revitalization and Innovation; Routledge: London, UK, 2010.

12. Yang, F. Religion in China. Survival and Revival under Communist Rule; Oxford University Press: New York, NY, USA, 2012.

13. Cao, N.; Giordan, G.; Yang, F. (Eds.) Chinese Religions Going Global. Annual Review of the Sociology of Religion; Briil: Leiden, The Netherlands, 2020; p. 11.

14. Feuchtwang, S. (Ed.) Handbook on Religion in China; Edward Elgar: Cheltenham, UK; Northampton, MA, USA, 2020.

15. Ammerman, N.T. Finding religion in everyday life. Sociol. Relig. 2014, 75, 189-207. [CrossRef]

16. Ammerman, N.T. Lived religion as an emerging field: An assessment of its contours and frontiers. Nord. J. Relig. Soc. 2016, 1, 83-99. [CrossRef]

17. Wagner, R. Godwired Religion, Ritual and Virtual Reality; Routledge: New York, NY, USA, 2012.

18. Campbell, H. Digital Religion. Understanding Religious Practice in New Media Worlds; Routledge: London, UK, 2013.

19. Merle, K. Religion in der Öffentlichkeit. Digitalisierung als Herausforderung für kirchliche Kommunikationskulturen (Religion in Public Sphere: Digitization as a Challenge for Church Communication Structures); De Gruyter: Berlin, Germany; Boston, MA, USA, 2019.

20. Llewellyn, D.; Trzebiatowska, M. Secular and religious feminisms: A future of disconnection? Fem. Theol. 2013, 21, 244-258. [CrossRef]

21. Pezzoli-Olgiati, D.; Rowland, C. Approaches to the Visual in Religion; Vandenhoeck \& Ruprecht: Göttingen, Germany, 2011.

22. Williams, R.R. (Ed.) Seeing Religion. Toward a Visual Sociology of Religion; Routledge: London, UK; New York, NY, USA, 2015.

23. Thumma, S.; Travis, D. Beyond Megachurch Myths: What We Can Learn from America's Largest Churches; Jossey-Bass: San Francisco, CA, USA, 2007.

24. Einstein, M. Brands of Faith: Marketing Religion in a Commercial Age; Routledge: London, UK, 2008.

25. Fath, S. Dieu XXL: La révolution des megachurches (Megachurches Revolution); Autrement: Paris, France, 2008.

26. Pace, E. Cristianesimo Extra-Large: La Fede Come Spettacolo di Massa (Extra-Large Christianity: Faith as Mass Spectacle); Edizioni Dehoniane: Bologna, Italy, 2018.

27. Bruce, S. Pray TV: Televangelism in America; Routledge: New York, NY, USA, 2019.

28. Possamai, A. The I-zation of Society, Religion and Neoliberal Post-secularism; Palgrave Macmillan: New York, NY, USA, 2018.

29. Arweck, E.; Bullivant, S.; Lee, L. (Eds.) Secularity and Non-Religion; Routledge: London, UK, 2014.

30. Lee, L. Recognizing the Non-religious: Reimagining the Secular; Oxford University Press: Oxford, UK, 2015.

31. Stolz, J.; Könemann, J.; Purdie, M.S.; Englberger, T.; Krüggeler, M. (Un)Believing in Modern Society. Religion, Spirituality, and Religious-secular Competition; Routledge: London, UK, 2016. 
32. Zuckerman, P. Faith No More: Why People Reject Religion; Oxford University Press: New York, NY, USA, 2011.

33. Thiessen, J.; Wilkins-Laflamme, S. Becoming a religious none: Irreligious socialization and disaffiliation. J. Sci. Study Relig. 2017, 56, 64-82. [CrossRef]

34. Terrin, A.N. Scientology. Libertà e Immortalità (Scientology. Freedom and Immortality); Morcelliana: Brescia, Italy, 2017.

35. Westbrook, D.A. Among the Scientologists: History, Theology and Praxis; Oxford University Press: New York, NY, USA, 2019.

36. Reece, G.L. UFO Religion: Inside Flying Saucer Cults and Culture; Tauris: New York, NY, USA, 2007.

37. Cusack, C.M. Invented Religions. Imagination, Fiction and Faith; Ashgate: Burlington, UK, 2010.

38. Ranzato, J. Le Tagliatelle in Piedi a Tutela Della Famiglia Tradizionale Pastafariana. Un'indagine Sulle Connessioni tra Attivismo Politico e Religioso nel Tessuto Urbano Italiano (Standing Tagliatelle Pasta to Protect the Traditional Pastafarian Family. An Investigation into the Connections between Political and Religious Activism in the Italian Urban Context). In Definire il Pluralismo Religioso; Saggioro, A., Ed.; Morcelliana: Brescia, Italy, 2020; pp. 233-258.

39. Possamai, A.; Blasi, A.J. The SAGE Encyclopedia of the Sociology of Religion; Sage: Thousand Oaks, CA, USA, 2020.

40. Swatos, W.H., Jr. (Ed.) Encyclopedia of Religion and Society; Altamira Press: Walnut Creek, CA, USA, 1998.

41. Johnson, T.; Zurlo, G. World Christian Encyclopedia; Edinburgh University Press: Edinburgh, UK, 2019.

42. Atran, S. Talking to Enemy: Violent Extremism, Sacred Values, and What It Means to the Human; Allen Lane: London, UK, 2010.

43. Wieviorka, M. The Lure of Anti-Semitism: Hatred of Jews in Present-Day France; Brill: Boston, MA, USA, 2007.

44. Moosavi, L. The racialization of Muslim converts in Britain and their experiences of islamophobia. Crit. Sociol. 2015, 41, 41-56. [CrossRef]

45. Hamilton, M. The Sociology of Religion; Routledge: London, UK, 2001.

46. Sharot, S.A. Comparative Sociology of World Religions; New York University Press: New York, NY, USA, 2001.

47. Dillon, M. (Ed.) Handbook of Sociology of Religion; Oxford University Press: New York, NY, USA, 2003.

48. Zuckerman, P. Invitation to the Sociology of Religion; Routledge: London, UK, 2003.

49. Roberts, K.A. Religion in Sociological Perspective; Wadsworth/Thomson: Belmont, CA, USA, 2004.

50. Ebaugh, H.R. (Ed.) Handbook of Religion and Social Institutions; Springer: New York, NY, USA, 2006.

51. Johnstone, R.L. Religion in Society. A Sociology of Religion, 8th ed.; Routledge: London, UK, 2007.

52. Beckford, J.A.; Demerath, N.J., III (Eds.) The SAGE Handbook of the Sociology of Religion; Sage: London, UK, 2007.

53. Christiano, K.J.; Swatos, W.H.; Kivisto, P. Sociology of Religion: Contemporary Developments; Rowman \& Littlefield Publishers: Lanham, MD, USA, 2008.

54. Lewis, J.R. (Ed.) The Oxford Handbook of New Religious Movements; Oxford University Press: Oxford, UK, 2008.

55. Lundskow, G.N. The Sociology of Religion: A Substantive and Transdisciplinary Approach; Sage: London, UK, 2008.

56. McGuire, M.B. Religion: The Social Context; Waveland Press: Long Grove, IL, USA, 2008.

57. Clarke, P.B. (Ed.) The Oxford Handbook of Sociology of Religion; Oxford University Press: Oxford, UK, 2011.

58. Davie, G. The Sociology of Religion. A Critical Agenda, 2nd ed.; Sage: London, UK, 2013.

59. Cipriani, R. Sociology of Religion. An Historical Introduction; Aldine de Gruyter: New York, NY, USA; Transaction: London, UK, 2015.

60. Arweck, E.; Guest, M. Religion and Knowledge. Sociological Perspectives; Routledge: London, UK, 2016.

61. Emerson, M.O.; Mirola, W.A.; Monahan, S.C. Religion Matters: What Sociology Teaches us about Religion in Our World; Routledge: London, UK, 2016.

62. Furseth, I.; Repstad, P. (Eds.) An Introduction to the Sociology of Religion: Classical and Contemporary Perspectives; Routledge: London, UK, 2016.

63. Yamane, D. (Ed.) Handbook of Religion and Society; Springer: Cham, Switzerland, 2016.

64. Pollack, D.; Krech, V.; Müller, O.; Hero, M. (Eds.) Handbuch Religionssoziologie; Spinger: Wiesbaden, Germany, 2018.

65. Cornelio, J.; Gauthier, F.; Martikainen, T.; Woodhead, L. (Eds.) Routledge International Handbook of Religion in Global Society; Routledge: London, UK, 2021.

66. Warner, R.S. Work in Progress toward a New Paradigm for the Sociological Study of Religion in the United States. Am. J. Soc. 1993, 98, 1044-1093. [CrossRef]

67. Young, A.L. (Ed.) Rational Choice Theory and Religion; Routledge: London, UK, 1997.

68. Berger, P.L. The Sacred Canopy. Elements of a Sociological Theory of Religion; Doubleday: Garden City, NY, USA, 1967.

69. Smilde, D. The Emerging Strong Program in the Sociology of Religion. Available online: https://tif.ssrc.org/2010/02/08/theemerging-strong-program-in-the-sociology-of-religion/ (accessed on 24 January 2021).

70. Smilde, D.A.; May, M. Causality, Normativity, and Diversity in 40 Years of U.S. Sociology of Religion: Contributions to Paradigmatic Reflection. Soc. Relig. 2015, 76, 369-388. [CrossRef]

71. Eisenstadt, S.N. (Ed.) Multiple Modernities; Routledge: London, UK; Transaction Publishers: New Brunswick, NJ, USA, 2002.

72. Davie, G.; Heelas, P.; Woodhead, L. (Eds.) Predicting Religion. Christian, Secular and Alternative Futures; Routledge: London, UK, 2003.

73. Smith, C. Future directions in the sociology of religion. Soc. Forces 2008, 86, 1561-1589.

74. Bender, C.; Cadge, W.; Levitt, P.; Smilde, D. (Eds.) Religion on the Edge: De-centering and Re-centering the Sociology of Religion; Oxford University Press: Oxford, UK, 2013.

75. Gle, N. Snapshots of Islamic modernities. Daedalus 2000, 129, 91-117. 
76. Salvatore, A. The Sociology of Islam: Knowledge, Power and Civility; Wiley: Chichester, UK, 2016.

77. Tu, W. Implications of the rise of 'Confucian' east Asia. Daedalus 2000, 129, 195-218.

78. Taylor, C. A Secular Age; The Belknap Press of Harvard University Press: Cambridge, MA, USA; London, UK, 2007.

79. Bellah, R. Religion in Human Evolution: From the Paleolithic to the Axial Age; The Belknap Press of Harvard University Press: Cambridge, MA, USA, 2011.

80. Bellah, R. Religious evolution. Amer. Sociol. Rev. 1964, 29, 358-374. [CrossRef]

81. Bellah, R.; Joas, H. (Eds.) The Axial Age and Its Consequences; The Belknap Press of Harvard University Press: Cambridge, MA, USA, 2012.

82. Enstedt, D.; Larsson, G.; Mantsinen, T.T. (Eds.) Handbook of Leaving Religion; Brill: Leiden, The Netherlands, 2019.

83. Rambo, L.R.; Farhadian, C.E. (Eds.) The Oxford Handbook of Religious Conversion; Oxford University Press: Oxford, UK, 2014.

84. King, U.; Beattie, T. Gender, Religion and Diversity. Cross-Cultural Perspectives; Continuum: London, UK; New York, NY, USA, 2004.

85. Feldman, J. Citizenship, Faith, and Feminism: Jewish and Muslim Women Reclaim their Rights; Brandeis University Press: Waltham, Ma, USA, 2011.

86. Levitt, P. God Needs no Passport: How Immigrants are Changing the American Religious Landscape; New York University Press: New York, NY, USA, 2007.

87. Gillespie, M.; Herbert, D.E.J.; Greenhill, A. (Eds.) Social Media and Religious Change; De Gruyter: Berlin, Germany; New York, NY, USA, 2013.

88. Granholm, K.; Moberg, M.; Sjö, S. (Eds.) Religion, Media, and Social Change; Routledge: London, UK, 2018.

89. Pokorny, L.; Winter, F. (Eds.) Handbook of East Asian New Religious Movements; Brill: Leiden, The Netherlands, 2018.

90. van der Veer, P. (Ed.) Handbook of Religion and the Asian City. Aspiration and Urbanization in the Twenty-First Century; University of California Press: Oakland, CA, USA, 2015.

91. Jerryson, M.; Juergensmeyer, M.; Kitts, M. (Eds.) The Oxford Handbook of Religion and Violence; Oxford University Press: Oxford, UK, 2013.

92. Dyrendal, A.; Robertson, D.G.; Asprem, E. (Eds.) Handbook of Conspiracy Theory and Contemporary Religion; Brill: Leiden, The Netherlands, 2018.

93. Gottlieb, R.S. (Ed.) The Oxford Handbook of Religion and Ecology; Oxford University Press: Oxford, UK, 2006.

94. Appleby, R.S.; Omer, A.; Little, D. (Eds.) The Oxford Handbook of Religion, Conflict, and Peacebuilding; Oxford University Press: Oxford, UK, 2015.

95. Becci, I.; Burchardt, M.; Casanova, J. (Eds.) Topographies of Faith. Religion in Urban Spaces; Brill: Leiden, The Netherlands, 2013.

96. Day, K.; Edwards, E.M. (Eds.) The Routledge Handbook of Religion and Cities; Routledge: London, UK, 2021.

97. Wieting, S.G. The Sociology of Hypocrisy. An Analysis of Sport and Religion; Routledge: London, UK, 2019.

98. Palmisano, S. Exploring New Monastic Communities. The (Re)invention of Tradition; Routledge: London, UK, 2019.

99. Meister, C. (Ed.) The Oxford Handbook of Religious Diversity; Oxford University Press: Oxford, UK, 2010.

100. Beckford, J.A.; Gilliat, S. Religion in Prison. "Equal Rites" in a Multi-Faith Society; Cambridge University Press: Cambridge, UK, 2005.

101. Becci, I.; Roy, O. (Eds.) Religious Diversity in European Prisons: Challenges and Implications for Rehabilitation; Springer International Publishing: Cham, Switzerland, 2016.

102. Di Gennaro, G.; Esposito, M. (Eds.) La Pena tra Misericordia e Afflizione. Una Ricerca Empirica sul Giubileo Delle Persone Detenute (Punishment between Mercy and Affliction. An Empirical Research on the Jubilee of Detained Persons.); Franco Angeli: Milano, Italy, 2020.

103. Fishman, J.; Omoniyi, T. (Eds.) Explorations in the Sociology of Language and Religion; J. Benjamins: Amsterdam, The Netherlands; Philadelphia, PA, USA, 2006.

104. McCleary, R.M. (Ed.) The Oxford Handbook of the Economics of Religion; Oxford University Press: Oxford, UK, 2011.

105. Ziebertz, H.-G.; Črpić, G. (Eds.) Religion and Human Rights. An International Perspective; Springer International Publishing: Cham, Switzerland, 2015.

106. Ferrari, S. (Ed.) Routledge Handbook of Law and Religion; Routledge: London, UK, 2017.

107. Breskaya, O.; Giordan, G.; Richardson, J. Human rights and religion: A sociological perspective. J. Sci. Study Relig. 2018, 57, 419-431. [CrossRef]

108. Giordan, G.; Zrinščak, S. One pope, two churches: Refugees, human rights and religion in Croatia and Italy. Soc. Comp. 2018, 65, 62-78. [CrossRef]

109. Breskaya, O.; Giordan, G. Measuring the Social Perception of Religious Freedom: A Sociological Perspective. Religions 2019, 10, 4. Available online: https:/ / www.mdpi.com/2077-1444/10/4/274 (accessed on 24 January 2021).

110. Giordan, G.; Zrinščak, S. (Eds.) Global Eastern Orthodoxy. Politics, Religion, and Human Rights; Springer International Publishing: Cham, Switzerland, 2020.

111. Norris, P.; Inglehart, R. Sacred and Secular Religion and Politics Worldwide; Cambridge University Press: New York, NY, USA, 2004.

112. Turner, B.S. The Religious and the Political. A Comparative Sociology of Religion; Cambridge University Press: Cambridge, UK, 2013.

113. Haynes, J. Routledge Handbook of Religion and Politics; Routledge: London, UK, 2016.

114. Beyer, P. Religion in the Context of Globalization. Essays on Concept, Form, and Political Implication; Routledge: London, UK, 2013.

115. Stausberg, M.; Engler, S. (Eds.) The Routledge Handbook of Research Methods in the Study of Religion; Routledge: London, UK, 2012.

116. Johnson, T.M.; Ross, K.R. (Eds.) Atlas of Global Christianity; Edinburgh University Press: Edinburgh, UK, 2009. 
117. Yang, F. Atlas of Religion in China: Social and Geographical Contexts; Brill: Leiden, The Netherlands, 2018.

118. Johnson, T.M.; Grim, B.J. (Eds.) World Religion Database; Brill: Leiden, The Netherlands; Boston, MA, USA, 2021.

119. Blasi, A.J.; Giordan, G. (Eds.) Sociologies of Religion: National Traditions; Brill: Leiden, The Netherlands, 2015.

120. Spickard, J.V. Alternative Sociologies of Religion: Through Non-Western Eyes; New York University Press: New York, NY, USA, 2017.

121. Köllner, T. (Ed.) Orthodox Religion and Politics in Eastern Europe: On Multiple Secularisms and Entanglements; Routledge: London, UK; New York, NY, USA, 2019.

122. Roudometof, V. Globalization and Orthodox Christianity: The Transformations of a Religious Tradition; Routledge: London, UK; New York, NY, USA, 2014; 2017 paperback.

123. Cipriani, R. Diffused Religion. Beyond Secularization; Palgrave Macmillan: Cham, Switzerland, 2017.

124. Cipriani, R. L'incerta fede. Un'indagine quanti-qualitativa in Italia (Uncertain faith. A quanti-qualitative survey in Italy); Franco Angeli: Milano, Italy, 2020.

125. Towler, R. The Need for Certainty. A Sociological Study of Conventional Religion, 1st ed.; Routledge: London, UK, 2020; first edition: 1984. 